\title{
The National Network of Seismic Stations of Slovakia - Current state after 13 years in operation from the project of modernization and enhancement
}

\author{
Kristián CSICSAY ${ }^{1, *}$, Andrej CIPCIAR ${ }^{1,2}$, Lucia FOJTÍKOVÁ ${ }^{1,3}$, \\ Miriam KRISTEKOVÁ ${ }^{1,2}$, Martin GÁLIS ${ }^{1,2}$, Miroslav SRBECKÝ ${ }^{1}$, \\ Zuzana CHOVANOVÁ ${ }^{1}$, Erik BYSTRICKÝ' ${ }^{1}$, Róbert KYSEL ${ }^{1,2}$ \\ ${ }^{1}$ Earth Science Institute of the Slovak Academy of Sciences, \\ Dúbravská cesta 9, P. O. Box 106, 84005 Bratislava, Slovak Republic \\ ${ }^{2}$ Faculty of Mathematics, Physics and Informatics Comenius University in Bratislava, \\ Mlynská dolina, 84248 Bratislava, Slovak Republic \\ ${ }^{3}$ Institute of Rock Structure and Mechanics of the Czech Academy of Sciences, \\ V Holesovickach 94/41, 182 09, Prague 8, Czech Republic
}

\begin{abstract}
We present the state of the modernized, upgraded and enhanced National Network of Seismic Stations (NNSS) of Slovakia at the end of the year 2017 and the importance of the Project: Modernization and enhancement of the National Network of Seismic Stations which took place in years 2001-2004. In this period some stations were modernized and upgraded and several new stations were built in various places in Slovakia to increase ability to localize seismic events on the territory of Slovakia and adjacent areas. Before the year 2001 the average number of localized earthquakes on the territory of Slovakia was only 7 per year. The breakthrough occurred in the year 2005 with the fully operational network when the number of localized earthquakes with epicentre on the territory of Slovakia was increased up to 50. Now this number is approximately 70-90 earthquakes per year. We present the changes in the NNSS in the last 13 years, obtained results (some of them are preliminary), advantages and weaknesses of the NNSS and future plans toward further improvements of our seismic network system.
\end{abstract}

Key words: Slovakia, National Network of Seismic Stations, earthquakes

\section{Introduction}

Before the year 2001 the NNSS consisted of six permanent seismic stations Hurbanovo (HRB), Košice (KOS), Modra (MOD), Šrobárová (SRO), Vyhne

\footnotetext{
*corresponding author: e-mail: kristian.csicsay@savba.sk
} 
(VYH) and Železná studnička (ZST) (Fig. 1). Due to the quality of seismic records and number and placement of seismic stations the ability to localize seismic events was at very low level (Moczo et al., 2005). The average number of localized earthquakes on the territory of Slovakia was only 7 per year (Cipciar et al., 2017). In the year 2001 a new very important and ambitious project was started which primary goal was to upgrade the NNSS to the standard European level at that time. The NNSS has been modernized and enhanced during the years 2001-2004. The Železná studnička seismic station was the only one at the European level at that time and only minimal upgrade was necessary. All other seismic stations (Modra, Šrobárová, Vyhne) required serious upgrades. Due to increased noise level, the seismic station Košice was cancelled from operation and moved to Červenica, where was a more suitable place for seismic recording. New seismic stations Iža, Kečovo, Kolonické sedlo, Likavka, Moča, Stebnícka Huta were built (Moczo et al., 2005). For each new seismic station a site selection process was car-

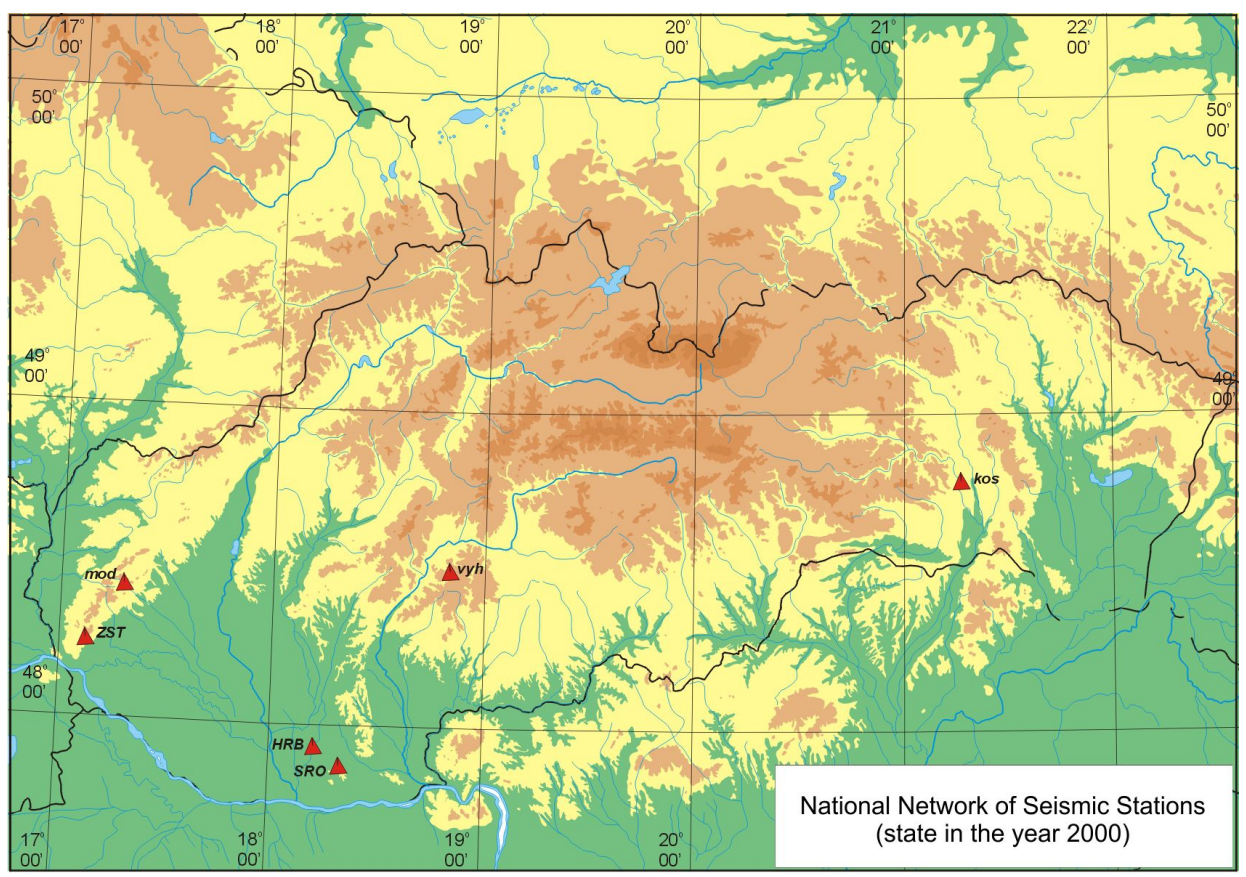

Fig. 1. State of the NNSS in the year 2001 after Moczo et al. (2005). 
ried out. A typical seismic station was equipped with a sensor (short period or broadband), 16bit digitizer, GPS, classic PC and satellite. Only the oldest seismic station Hurbanovo was not upgraded during the project. This seismic station has been in operation since 1909 (Pajdušák, 1997) and is equipped with two horizontal seismographs type Mainka and analogue registration on a smoked paper. After the end of the Project: Modernization and enhancement of the National Network of Seismic Stations the NNSS consisted of five broadband and seven short period seismic stations (Fig. 2) (Moczo et al., 2005). For more information about the beginnings and initial status of the modernized and enhanced NNSS see paper Labák (2004).

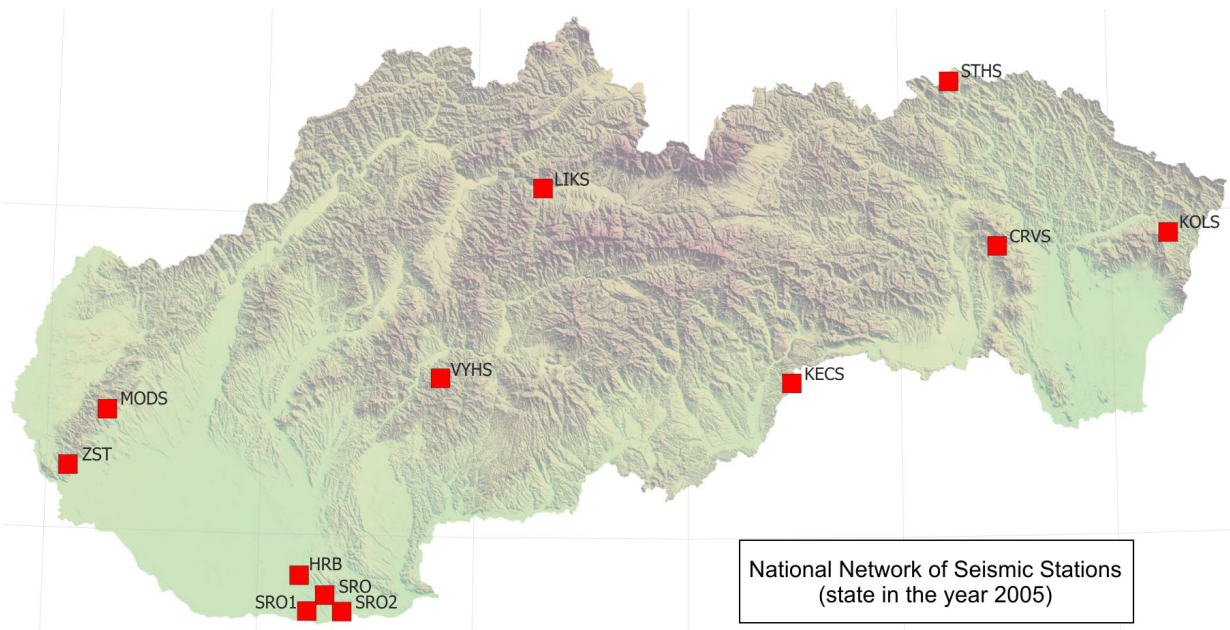

Fig. 2. State of the NNSS after the end of the Project: Modernization and enhancement of the National Network of Seismic Stations.

\section{Current state of the NNSS}

At the present, the NNSS (ESI SAS, 2004) is the most important Slovak infrastructure for monitoring of seismic activity. Its main mission and goal is to monitor and localize earthquakes with macroseismic effects (effects on people, objects, buildings and nature) on the territory of Slovakia. Besides these earthquakes the seismic stations of NNSS record also weaker local 
earthquakes and other seismic events (e.g. quarry blasts) as well as regional end teleseismic earthquakes and nuclear explosions. All permanent seismic stations are registered in the International Seismological Centre (ISC).

The network consists of eight short period and five broadband seismic stations (Fig. 3). Broadband stations are: Červenica (CRVS), Kolonické sedlo (KOLS), Modra (MODS), Vyhne (VYHS) and Železná studnička (ZST). Short period seismic stations are: Hurbanovo (HRB), Izabela (IZAB), Iža (SRO1), Kečovo (KECS), Liptovská Anna (LANS), Moča (SRO2), Stebnícka Huta (STHS) and Šrobárová (SRO). Some of them are in operation with original equipment since the installation, others have undergone upgrading process partly or completely (e.g. 24/32bit digitizers, $12 \mathrm{~V}$ mini-PC). Due to signal problem caused by increased level of background seismic noise the seismic station Likavka (LIKS) have been moved to the new location in Liptovská Anna in cooperation with the Progseis, Ltd. company in the year 2009 (Fig. 4). Almost 9 years of operation the Liptovská Anna (LANS) proves to be our best short period seismic station. In the year 2016 the seismic station IZAB has been added to the NNSS as a new permanent short period seismic station. This seismic station has been operated in cooperation with Progseis, Ltd. company. Three additional stations Banka (BAN), Podolie (POD), Jalšové (JAL) have been added to the NNSS in

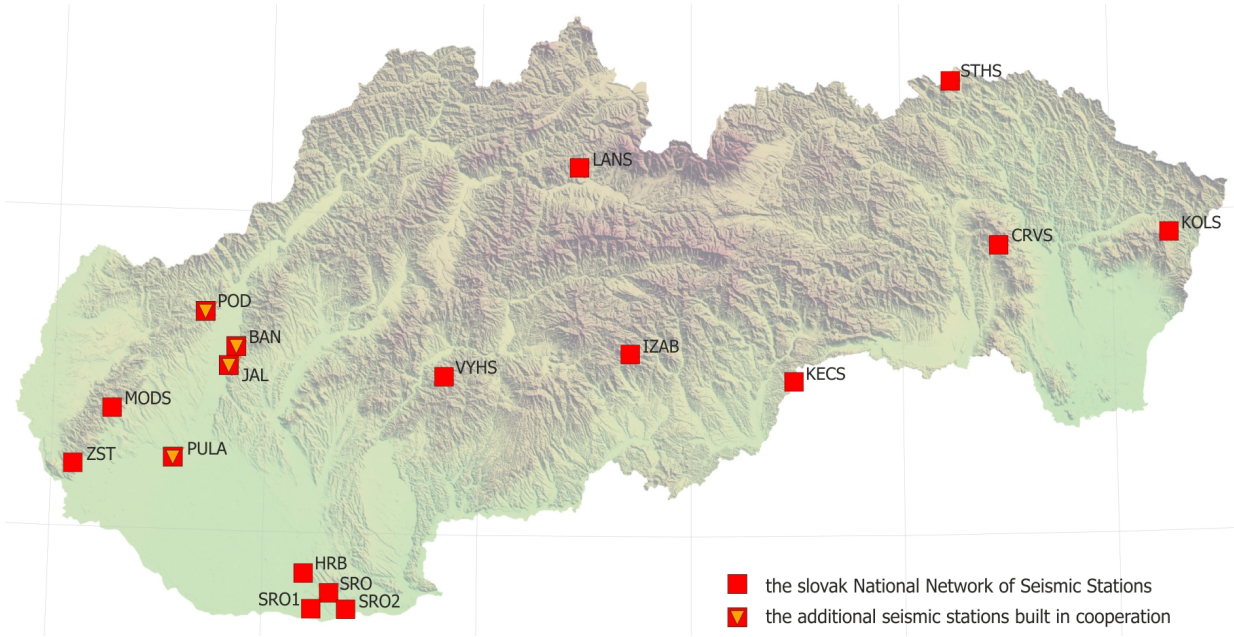

Fig. 3. Current state of the NNSS. 


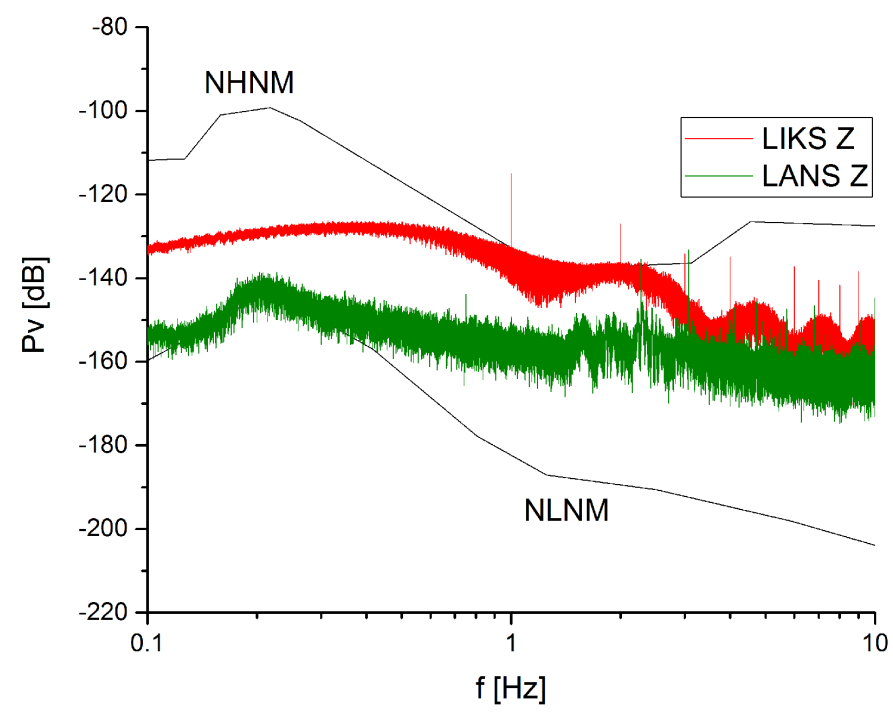

Fig. 4. Comparison of the data quality on the component $\mathrm{Z}$ of the seismic stations LIKS and LANS. NHNM and NLNM model is after Bormann and Wielandt (2002). NHNM - new high noise model, NLNM - new low noise model, Pv - velocity power spectral density.

the Little Carpathians (Fig. 3) in cooperation with Progseis, Ltd. company and Institute of Rock Structure and Mechanics of the Czech Academy of Sciences (Fojtiková et al., 2015). The seismic station Pusté Úlany (PULA) has been added to the NNSS in Podunajská nížina (Fig. 3) in cooperation with Institute of Rock Structure and Mechanics of the Czech Academy of Science.

Three basic types of stations can be classified: cave, vault and surface stations. The cave type stations are CRVS, IZAB, MODS, VYHS, ZST and these stations are mostly broadband stations. The vault type stations are KOLS, SRO, SRO1, SRO2, STHS.These seismic stations are short-period except KOLS, where a broadband sensor is installed. The surface stations, which are equipped with short-period sensors, are BAN, HRB, JAL, KECS, LANS, POD and PULA. For more details about seismic stations and their equipment see the website http://www.seismology.sk.

The data are transmitted from all seismic stations in real-time, except HRB - the reason mentioned above and are collected by the software pack- 
age SeisComp3 (Weber et al., 2007) through SeedLink server. For routine daily interpretation of collected data the Seismic Handler software package (Stammler, 1993) is used. Continuous raw seismic data from the NNSS are stored in a local archive and seismic data interpretations (together with information on equipment of stations) are stored in a web accessible database. Beside seismic data from the NNSS we also use seismic data from other local networks in Slovakia (Local Seismic Network of Eastern Slovakia, two private local seismic networks around nuclear power plants Jaslovské Bohunice and Mochovce) and seismic data from networks of neighbouring countries - Austrian Seismic Network (ZAMG - Zentralanstalt für Meterologie und Geodynamik, 1987), Czech Regional Seismic Network (Institute of Geophysics, Academy of Sciences of the Czech Republic, 1973), Hungarian National Seismological Network (Kövesligethy Radó Seismological Observatory, 1992), Local seismological network for monitoring NPP Dukovany (Institute of Physics of the Earth Masaryk University, 2014), GEOFON Seismic Network (GEOFON Data Center, 1993), Polish Seismological Network.

Daily seismic data from the NNSS are provided to the ORFEUS Data Center through GEOFON Data Center in Potsdam (GEOFON Data Center, 1993). From there other countries and institutions can download and use these data. Seismic data from the NNSS are used permanently for the daily interpretation of seismic events by neighbouring countries e.g. Bondár et al. (2018); Schneider et al. (2018); Yang et al. (2018).

All permanent seismic stations of the NNSS are included in the Central and East European Earthquake Research Network - $\mathrm{CE}^{3} \mathrm{RN}$ (Lenhardt et $a l ., 2014$ ) and three broadband stations MODS, VYHS and ZST are part of the AlpArray permanent seismic network (Hetényi et al., 2018).

\section{Preliminary results and results}

Although the Project: Modernization and enhancement of the National Network of Seismic Stations had indicated positive results already in the year 2004, the real breakthrough occurred in the year 2005 with the fully operational network. In this year the number of interpreted seismic events and phases (Graph 1) and localized earthquakes on the territory of Slovakia (Graph 2) increased dramatically compared to the year 2003 and sooner. 


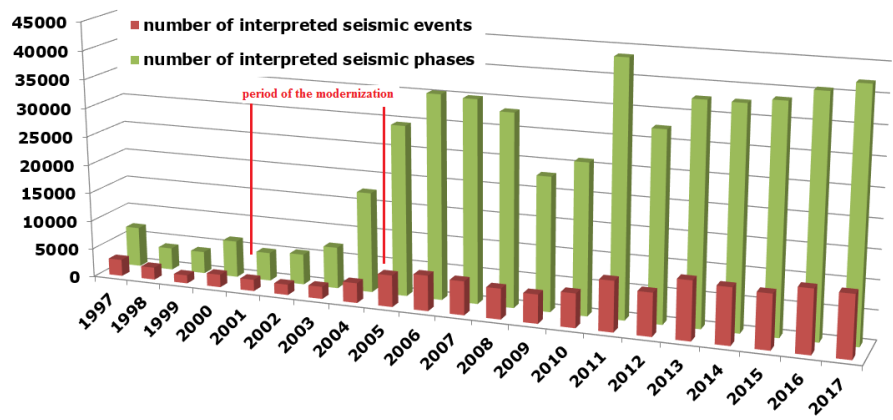

Graph 1. Number of interpreted seismic events and phases in the period 1995-2017.

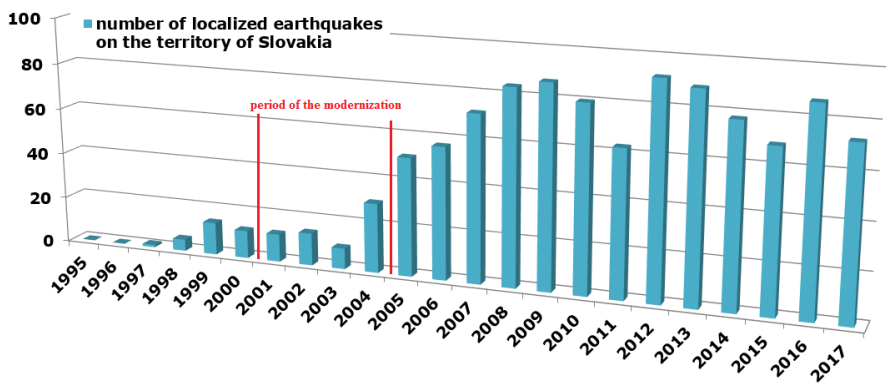

Graph 2. Number of localized earthquakes on the territory of Slovakia in the period 1995-2017.

Other very appropriate comparison of the old and the new NNSS is the ability to seismometrically localize earthquakes on the territory of Slovakia. Fig. 5 shows the number of seismometrically localized earthquakes in the period 1902-2003. During this period only 92 earthquakes were seizmometrically localized. Recently approximately 70-90 earthquakes with epicentre on the territory of Slovakia are localized every year, most of them (cca $97 \%$ ) are weak events with estimated local magnitudes below 2 (Cipciar et al., 2017).

The increase accuracy of localizations of earthquakes on the territory of Slovakia allows more precise definition of seismo-active areas and their active fault systems and helps us to eliminate mining events from the earthquake catalogue (Fig. 6). Thanks to modernized and enhanced seismic network, 


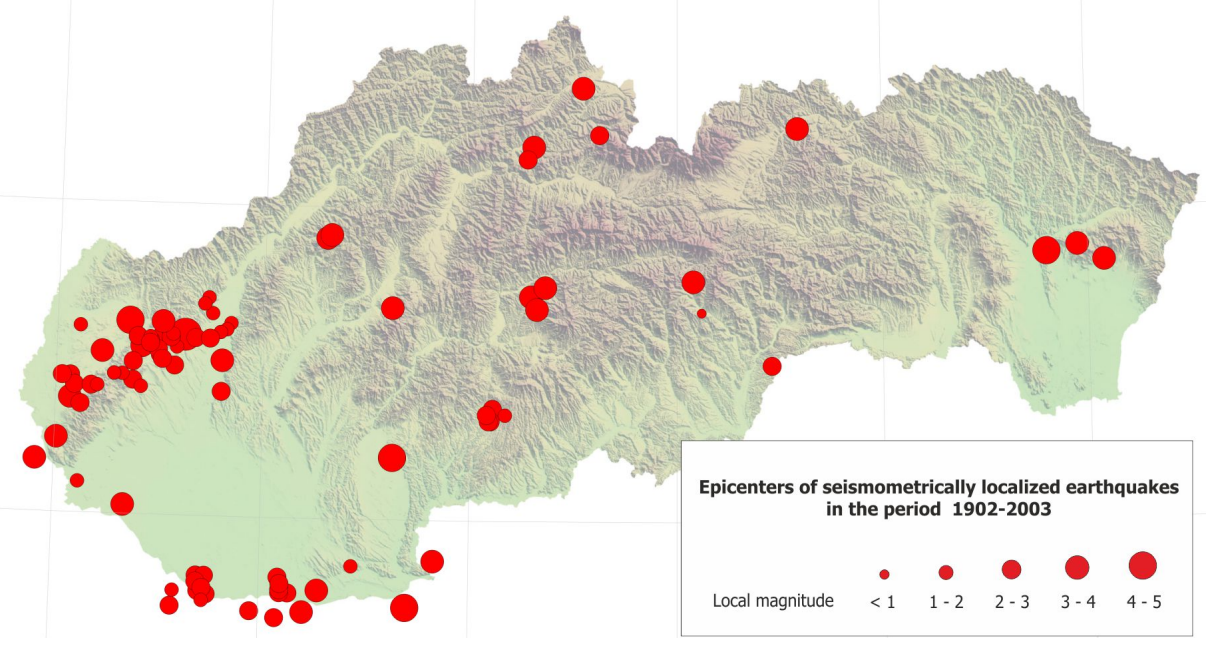

Fig. 5. Epicentres of seismometrically localized earthquakes on the territory of Slovakia by the old NNSS in the period 1902-2003.

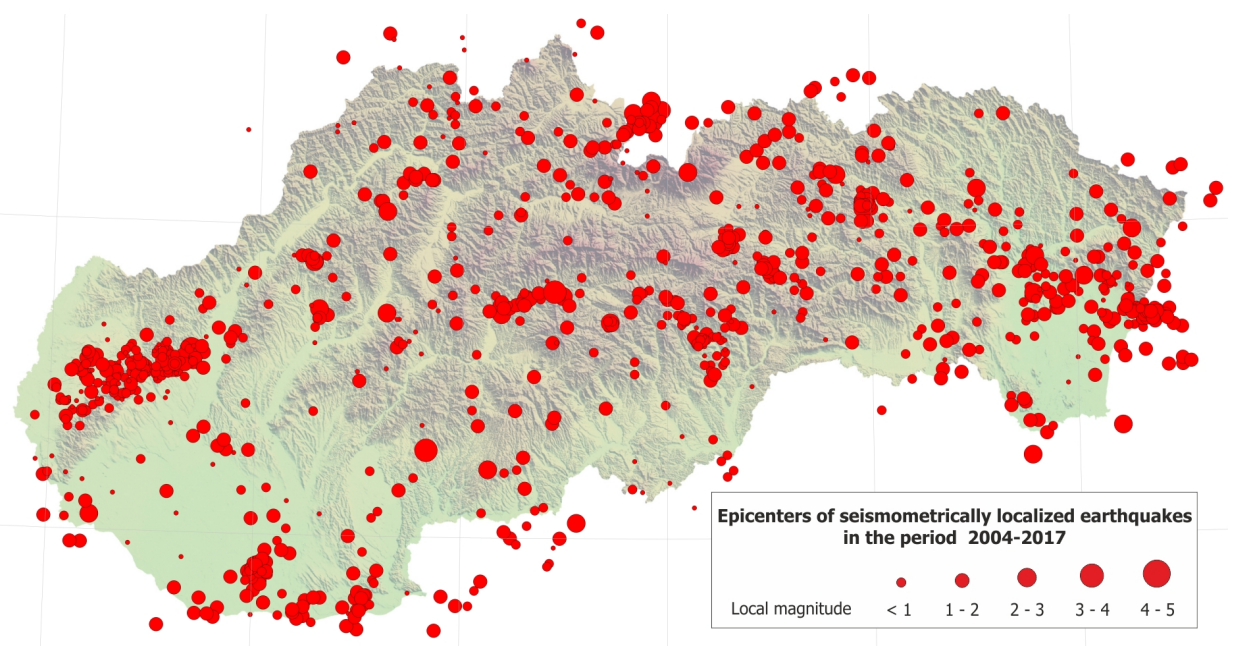

Fig. 6. Epicentres of seismometrically localized earthquakes on the territory of Slovakia and adjacent areas by the new NNSS in the period 2004-2017. 
localizations of earthquake epicentres confirm geological neotectonic and recently active fault zones (e.g. Fojtiková et al., 2010; Hók et al., 2014, 2016, 2018; Madarás et al., 2012; Marko et al., 2017). The hypocentres of these earthquakes indicate shallow earthquake activity on the territory of Slovakia with a maximum depth to $15 \mathrm{~km}$. We plan common geological and geophysical interpretation of the localized earthquakes together with geologists in the future.

The increased number of recorded and localized earthquakes by modernized NNSS allowed the determination of the new local magnitude formulae for the territory of Slovakia (Chovanová and Kristek, 2018). Until now the (Hutton and Boore, 1987) formula was used for estimation of the local magnitudes. One of the main motivations of developing the new formulae was the reduction of the differences between the local magnitudes estimated for one event at different seismic stations of the NNSS. The formulae was developed using 3579 trace amplitudes recorded by nine permanent seismic stations of the NNSS from 2005 until 2016. The formulae are valid from $10 \mathrm{~km}$ up to $550 \mathrm{~km}$ of epicentral distance. The attenuation parameters and also the station corrections for nine seismic stations were estimated. The range of the station corrections is -0.21 for VYHS up to 0.28 for KOLS. The smallest correction 0.03 is for CRVS and MODS station. Using the new formulae with the station corrections, the reduction of error is up to $58 \%$ comparing to formulae by Hutton and Boore (1987).

\section{Conclusion and discussion}

Period of 13 years of the seismic activity monitoring on the territory of Slovakia from a geological point of view is very short time but years 20042017 show enormous advances to understanding the seismic regime of active fault systems and geological evolution of tectonic units on the territory of Slovakia. Currently the new NNSS localize approximately ten times more earthquakes on the territory of Slovakia then the old NNSS. Localizations of earthquake epicentres confirm geological neotectonic and recently active fault zones.

However, the seismic monitoring in Slovakia should be further improved. Due to lack of strong earthquakes and missing temporary stations in the 
main seismo-active areas (except for the Little Carpathian seismic source zone), the ability of the calculation of focal mechanisms is at very low level. Recent years of data acquisition and processing showed the necessity to build additional stations in various parts of Slovakia, particularly in Spiš and Kysuce - Orava regions from where still we don't have enough information about the seismic regime in these seismo-active areas. On the other hands 13 years of monitoring is too much for seismological equipment. For this reason we need to replace outdated seismometers and data loggers with new modern instruments.

The results of seismic monitoring in Slovakia before and after modernization clearly demonstrate a success of the realization of the Project: Modernization and enhancement of the National Network of Seismic Stations and it's importance for a future seismological and tectonic research of the Slovak territory and adjacent areas.

Acknowledgements. The authors have been supported by the Slovak Foundation Grant VEGA 2/0188/15 and The Slovak Research and Development Agency Grant APVV-16-0146. The authors are thankful to prof. Peter Moczo for the realization and management of the Project: Modernization and enhancement of the National Network of Seismic Stations and also to other members of the team who contributed to modernization and helped to improve the operation of the National Network of Seismic Stations.

\section{References}

Bondár I., Mónus P., Czanik Cs., Kiszely M., Gráczer Z., Wéber Z., AlpArray Working Group, 2018: Relocation of Seismicity in the Pannonian Basin Using a Global 3D Velocity Model. Seismological Research Letters, 89, 6, 2284-2293, doi: 10.1785/022 0180143.

Bormann P., Wielandt E., 2002: Chapter 4: Seismic Signals and Noise (Version June 2013) In: Bormann P. (Ed.) 2002. IASPEI New Manual of Seismological Observatory Practice. GeoForschungsZentrum Potsdam, 1, 7, 1-62, doi: 10.2312/GFZ. NMSOP-2 -ch4.

Chovanova Z., Kristek J., 2018: A Local Magnitude Scale for Slovakia, Central Europe. Bulletin of the Seismological Society of America, 108, 5A, 2756-2763, doi : 10.1785/ 0120180059.

Cipciar A., Chovanová Z., Csicsay K., Kristeková M., Fojtíková L., Kysel R., Pažák P., Srbecký M., Bystrický E., Gális M., Kristek J., Moczo P., 2017: Slovak Earthquakes Catalogue, Version 2017. Earth Science Institute of the Slovak Academy of Sciences. 
ESI SAS (Earth Science Institute of the Slovak Academy of Sciences), 2004: National Network of Seismic Stations of Slovakia. Deutsches GeoForschungsZentrum GFZ, Other/Seismic Network, doi: 10.14470/FX099882.

Fojtíková L., Vavryčuk V., Cipciar A., Madarás J., 2010: Focal mechanisms of microearthquakes in the Dobrá Voda seismo-active area in the Malé Karpaty Mts. (Little Carpathians), Slovakia. Tectonophysics, 492, 213-229.

Fojtíková L., Kristeková M., Málek J., Sokos E., Csicsay K., Záhradník J., 2015: Quantifying capability of a local seismic network in terms of locations and focal mechanism solutions of weak earthquakes. Journal of Seismology, 20, 1, doi: 10.1007/s10950 -015-9512-1.

GEOFON Data Center, 1993: GEOFON Seismic Network. Deutsches GeoForschungsZentrum GFZ, Other/Seismic Network, doi : 10.14470/TR560404.

Hetényi Gy., Molinari I., Clinton J., Bokelmann G., Bondár I., Crawford W. C, Dessa J.X., Doubre C., Friederich W., Fuchs F., Giardini D., Gráczer Z., Handy M. R., Herak M., Jia Y., Kissling E., Kopp H., Korn M., Margheriti L., Meier T., Mucciarelli M., Paul A., Pesaresi D., Piromallo C., Plenefisch T., Plomerová J., Ritter J., Rümpker G., Šipka V., Spallarossa D., Thomas Ch., Tilmann F., Wassermann J., Weber M., Wéber Z., Wesztergom V., Živčić M., AlpArray Seismic Network Team, AlpArray OBS Cruise Crew, AlpArray Working Group, 2018: The AlpArray seismic network: A large-scale European experiment to image the Alpine orogen. Surveys in Geophysics, 39, 5, 1009-1033, doi: 10.1007/s10712-018-9472-4.

Hók J., Šujan M., Šipka F., 2014: Tectonic division of the Western Carpathians: an overview and a new approach. Acta Geologica Slovaca, 6, 2, 135-143. (in Slovak with English Summary).

Hók J., Kysel R., Kováč M., Moczo P., Kristek J., Kristeková M., Šujan M., 2016: A seismic source zone model for the seismic hazard assessment of Slovakia. Geologica Carpathica, 67, 3, 273-288.

Hók J., Littva J., Šujan M., Šamajová L., Šujan M., Šipka F., 2018: Geological structure of the Dobrá Voda seismoactive area (western Slovakia). Acta Geologica Slovaca, 10, 2 , in press.

Hutton L., Boore D. M., 1987: The ML scale in southern California, Bulletin of the Seismological Society of America, 77, 2074-2094.

Institute of Geophysics, Academy of Sciences of the Czech Republic, 1973: Czech Regional Seismic Network. International Federation of Digital Seismograph Networks, Other/Seismic Network, doi: 10.7914/SN/CZ.

Institute of Physics of the Earth Masaryk University (Czech), 2014: IPE_EDU. International Federation of Digital Seismograph Networks, Other/Seismic Network, doi: 10.7914/SN/D1.

Kövesligethy Radó Seismological Observatory (Geodetic and Geophysical Institute, Research Centre for Astronomy and Earth Sciences, Hungarian Academy of Sciences (MTA CSFK GGI KRSZO)), 1992: Hungarian National Seismological Network. Deutsches GeoForschungsZentrum GFZ. Other/Seismic Network, doi : 10.14470/UH 028726 . 
Labák P., 2004: Slovak National Network of Seismic Stations - an overview. Geophysical Instute, Slovak Academy of Sciences, 8, http://www.fdsn.org/media/meetings/ 2004/Slovak_FDSN_2004.pdf.

Lenhardt W., Pesaresi D., Živčić M., Costa G., Kuk K., Bondár I., Duni L., Spacek P., Dimitrova L., Popa M., 2014: Central and East European Earthquake Research Network. International Federation of Digital Seismograph Networks, Other/Seismic Network, doi: 10.7914/SN/C3.

Local Seismic Network of Eastern Slovakia. Faculty of Mathematics, Physics of the Earth and Informatics, Comenius University, http://www.fyzikazeme.sk/mainpage/ind ex_en.htm.

Madarás J., Fojtíková L., Hrašna M., Petro L., Ferianc, D., Briestenský M., 2012: Definition of the seismic active regions in Slovakia based on historical earthquake records and current monitoring of tectonic and seismic activity. Mineralia Slovaca, 44, 351-364. (in Slovak, English resume).

Marko F., Andriessen P. A. M., Tomek Č., Fojtíková L., Bošanský M., Piovarči M., Reichwalder P., 2017: Carpathian Shear Corridor - A strike-slip boundary of an extruded crustal segment. Tectonophysics, 703-704, 119-134, doi: 10.1016/j.tecto. 2017 .02 .010 .

Moczo P., Labák P., Kristek J., 2005: Modernizácia a doplnenie Národnej siete seizmických staníc. Záverečná správa za celú dobu riešenia projektu 2/9011/21. Geofyzikálny ústav Slovenskej akadémie vied, Bratislava, 36 (in Slovak).

Pajdušák P., 1997: Historical seismic instrumens at the stations Hurbanovo (HRB) and Skalnaté pleso (SPC) of Slovakia. Cahiers du Centre Européen de Géodynamique et de Séismologie, 13, 49-60.

Polish Seismological Network (PLSN), Institute of Geophysics Polish Academy of Sciences, https://www.igf.edu.pl/stacje-en.php.

Schneider F. M., Fuchs F., Kolinsky P., Caffagni E., Dorninger M., Serafin S., Bokelmann G., AlpArray Working Group, 2018: Seismo-acoustic signals of the Baumgarten (Austria) gas explosion detected by the AlpArray seismic network. Earth and Planetary Science Letters, 502, 104-114, doi: 10.1016/j.epsl.2018.08.034.

Stammler K., 1993: Seismichandler-Programmable multichannel data handler for interactive and automatic processing of seismological analyses. Computers \& Geosciences, 19, 2, 135-140, doi : 10.1016/0098-3004(93)90110-Q.

Yang L., Stehly L., Paul A., AlpArray Working Group, 2018: High-resolution surface wave tomography of the European crust and uppermost mantle from ambient seismic noise. Geophysical Journal International, 214, 2, 1136-1150, doi: 10.1093/gji/gg y188.

Weber B., Becker J., Hanka W., Heinloo A., Hoffmann M., Kraft T., Pahlke D., Reinhardt J., Thoms H., 2007: SeisComp3 - automatic and interactive real time data processing. Geophysical Research Abstracts In EGU General Assembly, 9, 09129.

ZAMG - Zentralanstalt für Meterologie und Geodynamik, 1987: Austrian Seismic Network. International Federation of Digital Seismograph Networks, Other/Seismic Network, doi: 10.7914/SN/OE. 